\title{
Butterflies Recorded on Flattop Mountain, Anchorage, Alaska
}

\author{
LANCE A. DURDEN
}

Department of Biology, Georgia Southern University, Statesboro, Georgia 30460-8042 USA; e-mail: ldurden@georgiasouthern.edu

Durden, Lance A. 2011. Butterflies recorded on Flattop Mountain, Anchorage, Alaska. Canadian Field-Naturalist 125(4): 357-358.

Eleven species of butterflies were recorded on Flattop Mountain, Anchorage, Alaska, during a four-day period in July 2006 : Colias philodice vitabunda (Clouded Sulphur), Pieris angelika angelika (Arctic White), Lycaena dorcas arcticus (Dorcas Copper), Plebejus glandon bryanti (Arctic Blue), Plebejus idas alaskensis (Northern Blue), Plebejus optilete yukona (Cranberry Blue), Boloria charliclea butleri (Purplish Fritillary), Boloria alaskensis alaskensis (Mountain Fritillary), Speyeria mormonia bischoffii (Mormon Fritillary), Oeneis bore mckinleyensis (White-veined Arctic), and Carterocephalus palaemon skada (Arctic Skipperling). Based on previously published distribution maps, the records for Plebejus idas and P. optilete represent range extensions; $P$. optilete was relatively common in sheltered valleys on the mountain.

Key Words: butterflies, Northern Blue, Plebejus idas, Cranberry Blue, Plebejus optilete, range extensions, Alaska, Anchorage.

From 18 to 21 July 2006, I recorded butterflies along the Flattop Mountain Trail in Chugach State Park $\left(61^{\circ} 04^{\prime} 59^{\prime \prime} \mathrm{N}, 149^{\circ} 39^{\prime} 10^{\prime \prime} \mathrm{W}\right)$, about $10 \mathrm{~km}$ southeast of Anchorage, near the base of the Kenai Peninsula in Alaska, U.S.A. This is the most frequently climbed mountain in Alaska, with a starting (parking lot) elevation of $688 \mathrm{~m}$ and a peak elevation of $1070 \mathrm{~m}$ (Zimmerman 1997).

Butterflies were mainly active in wind-sheltered valleys with abundant wild flowers when the sun was not obscured by clouds but, during cloud cover, some butterflies were observed nectaring on, or clinging to, flowers. Butterflies were recorded along, or adjacent to, the hiking trail from 12:00 to 17:00 each day; maximum daily temperatures on the mountain during the fourday period ranged from 12 to $16^{\circ} \mathrm{C}$. Specimen photographs deposited in the Department of Biology, Georgia Southern University (accession numbers L-3356 to L-3366), serve as vouchers for these records (Macadam 2006). Butterfly taxonomy follows Pelham (2011). The species and subspecies, numbers, sexes (if easily determined), and elevational distributions of the 11 species of butterflies recorded were as follows.

\section{Pieridae}

Colias philodice vitabunda Hovanitz (Clouded Sulphur): 35 males, 8 females (790-1050 m).

Pieris angelika angelika Eitschberger (Arctic White): 3 males (690-824 m).

\section{Lycaenidae}

Lycaena dorcas arcticus (Ferris) (Dorcas Copper): 1 male (1070 m; hilltopping on mountain peak).

Plebejus glandon bryanti Leussler (Arctic Blue): 2 males $(826 \mathrm{~m})$.

Plebejus idas alaskensis Chermock (Northern Blue): 2 males, 1 female $(732-826 \mathrm{~m})$.

Plebejus optilete yukona Holland (Cranberry Blue): 18 males, 2 females ( $700-870 \mathrm{~m})$.

Nymphalidae (sexes not determined)

Boloria chariclea butleri (Edwards) (Purplish Fritillary): 42 (730-1038 m).
Boloria alaskensis alaskensis (Holland) (Mountain Fritillary): 8 (730-1066 m).

Speyeria mormonia bischoffii (Edwards) (Mormon Fritillary): 51 (778-1022 m).

Oeneis bore mckinleyensis dos Passos (White-veined Arctic): 6 (822-1065 m).

Hesperiidae (sex not determined)

Carterocephalus palaemon skada (Edwards) (Arctic Skipperling): 1 (688 m).

According to published distribution maps, two of the lycaenid species reported here, Plebejus idas and $P$. optilete, have not previously been recorded as far south as the Kenai Peninsula in south-central Alaska (Scott 1986; Opler 1999; Brock and Kaufman 2003). Some of these works use different generic names for the two species, but the specific and common names are the same in all. Appreciating that the published range maps are schematic, I note that the southern range limit of $P$. idas in this part of Alaska is shown by Scott (1986) as $\sim 30 \mathrm{~km}$ to the north of Flattop Mountain and the southern range limit of P. optilete as $\sim 100 \mathrm{~km}$ to the north of this site (Scott 1986). Opler (1999) and Brock and Kaufman (2003) show the southern limits in this part of Alaska to be $\sim 100 \mathrm{~km}$ and $200 \mathrm{~km}$ to the north of Flattop Mountain, respectively, for these two species. Also, in a website on butterflies of the Anchorage area, Hopson (no date*) provides images of $P$. idas from Mount Baldy, about $30 \mathrm{~km}$ to the north of Flattop Mountain.

Despite the lack of previously published records, it is likely that both $P$. idas and P. optilete are fairly widely distributed in the Kenai Peninsula to the south of Flattop Mountain and also in suitable habitats to the north, east, and west of Flattop Mountain. Other butterfly records documented here are noteworthy because a list of butterflies and their elevational distributions on Flattop Mountain have not previously been published. 
Documents Cited (marked * in text)

Hopson, M. n.d. Butterflies along Alaska's hiking trails. http:www.turtlepuddle.org/alaskan/ak_butterflies.html.

\section{Literature Cited}

Brock, J. P., and K. Kaufman. 2003. Kaufman field guide to butterflies of North America. Hillstar Editions L.C. and Houghton Mifflin, New York. 392 pages.

Macadam, C. 2006. Embiopteran tools: "voucher" photography with digital cameras. Antenna: Bulletin of the Royal Entomological Society 30: 131-133.

Opler, P. A. 1999. A field guide to western butterflies. Second edition. Peterson Field Guide series. Houghton Mifflin, Boston. 540 pages.
Pelham, J. P. 2011. A catalogue of the butterflies of the United States and Canada with a complete bibliography of the descriptive and systematic literature. Revised 27 November 2011. 658 pages. http://butterfliesofamerica.com/USCan-Cat-1-30-2011.htm.

Scott, J. A. 1986. The butterflies of North America: a natural history and field guide. Stanford University Press, Stanford. 583 pages.

Zimmerman, J. 1997. A naturalist's guide to Chugach State Park, Alaska. Second edition. Alaska Natural History Association, Anchorage. 258 pages.

Received 7 September 2011

Accepted 14 November 2011 